\title{
Віртуальне навчання як головний вектор нової інформаційної епохи
}

\section{Половая Н. О., Національний авіаційний університет}

Використання технологій віртуальної реальності в освіті спричинило появу віртуального освітнього середовища, в рамках якого можна здійснювати безперервну самореалізацію та саморозвиток вільної, активної та творчої особистості за умов організації і функціонування відкритих освітніх систем на основі технологій віртуальної реальності. В освітньому процесі домінує інтерактивне самонавчання за наявності постійного зворотного зв'язку в системі «викладач-студент», а організація самостійної роботи спрямована на розвиток умінь творчості, пізнавальної діяльності та системності мислення суб'єктів навчання. Важливими компонентами є забезпечення доцільності навчання за рахунок дотримання пріоритету навчання перед викладанням; передавання діяльністного типу навчання; організації самостійної навчальної діяльності; підвищення мотивації навчання за допомогою використання засобів комплексного представлення та маніпулювання аудіовізуальною інформацією; підвищення рівня емоційного сприйняття інформації та формування навичок реалізовувати різні форми самостійної діяльності щодо обробки та аналізу інформації. Віртуальне освітнє середовище є типовим творчим середовищем саморозвитку відкритої та активної людини, якій притаманна активність, висока самооцінка, воля, а також свобода міркувань. Переважаючим у віртуальному освітньому середовищі є метод інтерактивного самонавчання із постійною співпрацею суб'єктів викладання та суб'єктів навчання за умови присутності безперервних зворотних зв'язків між ними.

Ключові слова: віртуальна освіта; віртуальна реальність; віртуалізація; освітнє середовище; освітній процес

\section{Virtual study as a main vector of new information epoch}

\section{Polovaya N. A., National aviation university}

Using technologies of virtual reality in studies caused appearance of virtual studying environment. In its content free, active and creative personality may realize its continuous self-actualization and self-development under conditions of organization and functioning of open study systems based on virtual reality technologies. Interactive self-studying dominates in the studying process having continuous connection in the system "teacher-student" and the organization of self-reliant work is aimed at development of creation, cognitive activity and system thinking skills. The important components are ensuring expediency of study with its priority in comparison with teaching, predominance of active study type, organization of self-reliant study, increase study motivation using means of complex presentation and manipulation of audiovisual information, increasing level of information emotional perception and formation of skills to realize different forms of self-reliant activity for information analysis. Virtual study environment is a typical for self-development of open-minded active person with 2 high self-rating, will and freedom of mind. In the virtual study environment prevles method of interactive self-education with constant cooperation of teaching subjects with study subjects under condition of constant reverse connections between them.

So, in the education system, the search for new forms of learning began. One of them was distance learning, continuing education, transnational learning, virtual education using network information technologies.

Thus, the virtualization of education reveals fundamentally new opportunities for overcoming the two most important and pressing problems of modern society:

- $\quad$ increasing accessibility to the openness of the quality education (including for disabled);

- the continuity of the learning process throughout human life, which today is a commonly accepted need and requirement proclaimed in UNESCO documents.

At the same time, it must be remembered that the virtual education system can not be recognized as complete because it is fundamentally unable to completely replace the personal contact between a student and a teacher, the processes of their personal communication and interaction.

The development of virtual reality, the transformation into the everyday communication processes carried out within its framework, is an essential prerequisite for the development of distance learning.

Keywords: virtual education; virtual reality; virtualization; educational environment; educational process

\section{Виртуальное обучение как главный вектор новой информационной эпохи}

\section{Половая Н. А., Национальный авиационный университет}

Использование технологий виртуальной реальности в образовании повлекло появление виртуальной образовательной среды, в рамках которой можна создавать беспрерывную самореализацию и саморазвитие свободной, активной и творческой личности при условии организации и функционировании открытых образовательных систем на основании технологий виртуальной реальности. В образовательном процессе доминирует интэрактивное самообучение при наличии постоянной обратной связи в системе «преподаватель-студент», а организация самостоятельной работы направлена на развитие умения творчества, познавательной деятельности и системности мышления субъектов обучения. Важными компонентами является обеспечение целесообразности учебы за счет 
соблюдения приоритета учебы перед преподаванием; передача деятельностного типа учебы; организации самостоятельной учебной деятельности; повышение мотивации учебы с помощью использования средств комплексного представления и манипулирования аудиовизуальной информацией; повышение уровня эмоционального восприятия информации и формирование навыков реализовывать разные формы самостоятельной деятельности по-поводу обработки и анализа информации. Виртуальная образовательная среда является типичной творческой средой саморазвития открытого и активного человека, которому присуща активность, высокая самооценка, воля, а также свобода соображений. Преобладающим в виртуальной образовательной среде является метод интерактивного самопознания с постоянным сотрудничеством субъектов преподавания и субъектов обучения при условии присутствия беспрерывных обратных связей между ними.

Ключевые слова: виртуальное образование; виртуальная реальность; виртуализация; образовательная среда; образовательный процесс

\section{Постановка проблеми.}

Ш видкі зміни в суспільстві, зумовлені бурхливим розвитком інформаційно-комунікаційних технологій, ставлять перед системою освіти завдання створення нового освітнього середовища для забезпечення якісної підготовки сучасних фахівців. Освітне середовище виступає системою психологічних, педагогічних, соціальних умов і впливів, які утворюють можливість для розкриття здібностей та особистісних характеристик суб'єктів освітнього середовища, так і тих, які ще не виявилися. В цьому контексті актуальне значення отримує нова форма освіти - віртуальна.

\section{Аналіз досліджень і публікацій.}

Різні аспекти проблеми освітнього середовища розлянуті в дослідженнях як класичних (Я. А. Коменський, Дж. Локк, Ж. Ж. Руссо, І. Г. Песталоцці та ін.), так і сучасних (С. Дерябо, В. Лебедєва, В. Орлова, В. Панова, М. Князєва, Ю. Мануйлов, В. Ясвін та ін.).

3 розвитком інформаційно-комунікаційних технологій та їх широкого застосування в освітній практиці постала актуальною проблематика взаємодії закритих освітніх систем та соціального середовища. Дана обставина розкрита в розвитку соціально-філософського дискурсу про віртуальну реальність (А. Бюль, М. Вейнстейн, Д. Ланьє, А.Крокер);увикористанніінформаційно-комунікаційних технологій в освіті та організації систем відкритої віртуальної освіти (А. П. Сршов, В. П. Зінченко, М. М. Моісєєв, В. М. Монахов, В. С. Лєдньов, М. П. Лапчик, В. Ю. Биков, В. М. Глушков, М. І. Жалдак, В. С. Михалевич, Ю. І. Машбиць, Ю. А. Бикадоров, А. Т. Кузнєцов, I. А. Новик, А. І. Павловський та ін.). У цих роботах досліджуються можливості, що пов'язані iз застосуванням інформаційно-комунікаційних технологій, присвячені питанням актуалізації концепції безперервної освіти, переходу від «освіти на все життя» до «освіти протягом усього життя», практичної реалізації особистої освітньої парадигми.

Мета дослідження - проаналізувати специфіку віртуального навчання в контексті інформатизації суспільства.

\section{Виклад основного матеріалу.}

З приходом XXI століття стає помітнішою нова тенденція соціальних змін, що отримала назву віртуалізації суспільства. Сутність даної тенденції полягає в тому, що на сьогоднішній день у багатьох життєво важливих сферах життєдіяльності суспільства (науці, економіці, політиці, освіті) все більше і більше спостерігається заміщення реальних речей та реальних дій їх штучно створеними образами, які $є$ тільки символами цих речей та дій. Інакше кажучи, сучасне суспільство активно створює навколо себе новий, «уявний світ символів, що існує паралельно з реальним фізичним світом та стає такою ж частиною буття, як і фізична реальність» $[1$, с. 116].

Популярності набуває питання науково обгрунтованого визначення поняття віртуального освітнього середовища та конкретизації шляхів здійснення освітнього процесу, в рамках якого можливе ефективне використання інформаційно-комунікаційних технологій в освітніх системах. Одним із таких шляхів $є$ створення і поширення віртуального освітнього середовища - відкритої системи, в рамках якої на основі застосування технологій віртуальної реальності забезпечується ефективне інтерактивне самонавчання в освітньому процесі.

Безумовно, віртуальне освітнє середовище $\epsilon$ суспільним феноменом реальної дійсності, але його дидактичний потенціал залишається розкритим не в повному обсязі, тому що наявні протиріччя між вимогами освітньої практики в ефективному освітньому середовищі та становищем наукового знання про них. Вагомою проблемою $\epsilon$ створення моделі віртуального освітнього середовища та визначення шляхів оптимального застосування технологій віртуальної реальності в освітній системі.

Використання технологій віртуальної реальності в освіті спричинило появу віртуального освітнього середовища, в рамках якого можна здійснювати безперервну самореалізацію та саморозвиток вільної, активної та творчої особистості за умов організації і функціонування відкритих освітніх систем на основі технологій віртуальної реальності. В освітньому процесі домінує інтерактивне самонавчання за наявності постійного зво- 
ротного зв'язку в системі «викладач - студент», а організація самостійної роботи спрямована на розвиток умінь творчості, пізнавальної діяльності та системності мислення суб'єктів навчання. Важливими компонентами є забезпечення доцільності навчання за рахунок дотримання пріоритету навчання перед викладанням; передавання діяльнісного типу навчання; організації самостійної навчальної діяльності; підвищення мотивації навчання за допомогою використання засобів комплексного представлення та маніпулювання аудіовізуальною інформацією; підвищення рівня емоційного сприйняття інформації та формування навичок реалізовувати різні форми самостійної діяльності щодо обробки та аналізу інформації.

Віртуальне освітне середовище виступає творчим середовищем, навчання в якому можливе за присутності високої внутрішньої мотивації студентів, їх емоційного налаштування та позитивного, оптимістичного настрою. Важливою умовою навчання у віртуальному освітньому середовищі $є$ активізація особистої освітньої парадигми. Ступінь довіри викладачів до ініціатив та креативності студентів в такій системі вища, ніж у традиційній системі освіти. При цьому діяльність студентів залишається високою тому, що технології активної творчої діяльності на основі інформаційно-комунікаційних технологій надають базові можливості для самореалізації студента, будучи важливим елементом забезпечення ефективного навчального процесу.

Запровадження інформаційно-комунікаційних технологій з використанням мультимедійних технологій та віддаленого доступу до інформаційно-освітніх ресурсів забезпечують безперервність віртуальної освіти, а можливість вибору плану та методики навчання сприяє виявленню у студентів індивідуальних творчих здібностей. Актуалізація інтенсивних форм навчання, а особливо при організації самостійної навчальної активності у віртуальному освітньому середовищі, $є$ важливим чинником підвищення мотивації до навчально-пізнавальної діяльності, збільшення рівня емоційного сприйняття нового матеріалу. У віртуальному освітньому середовищі формується сукупність умов, які сприяють процесу активної взаємодії між викладачами та студентами за допомогою орієнтації на здійснення різних видів самостійної роботи, враховуючи й інформаційно-навчальну, експериментально-дослідницьку, науково-практичну діяльність на базі інформаційних технологій.

Результати закордонних досліджень свідчать про те, що студенти мають достатньо уявлень щодо дидактичного потенціалу віртуального освітнього середовища і адекватні уявлення про можливості організації навчання у сучасному світі з точки зору самостійного планування навчання. Вони оцінюють особистісно-орієнтований характер потенціалу віртуального освітнього середовища, що свідчить про їх готовність обирати алгоритм вивчення навчального матеріалу та час навчання.

Віртуальна реальність із використанням інформаційно-комунікаційних технологій в навчанні сприяє формуванню інтерактивного освітнього віртуального середовища за допомогою користування сукупності засобів, методів формування та реалізації віртуальних образів з метою ефективної взаємодії з ними або всередині них, а також із високим рівнем достовірності. Віртуальне освітне середовище, масовий і одночасно цілеспрямований процес, розвиток якого можна чітко побачити на сучасному етапі розвитку і $є$ відкритою системою, що являє собою взаємозв'язок засобів та способів нових інформаційно-комунікаційних технологій, а також комунікаційних можливостей для забезпечення ефективної освіти за присутності інтерактивної взаємодії всіх суб'єктів навчального процесу.

Віртуальне освітнє середовище $є$ типовим творчим середовищем саморозвитку відкритої та активної людини, якій притаманна активність, висока самооцінка, воля, а також свобода міркувань. Переважаючим у віртуальному освітньому середовищі є метод інтерактивного самонавчання iз постійною співпрацею суб'єктів викладання та суб'єктів навчання за умови присутності безперервних зворотних зв'язків між ними.

В умовах віртуалізації та інформатизації суспільства, моделювання віртуального освітнього середовища служить базою для виявлення потенціалу сучасного освітнього середовища та можливостей його практичного втілення в освітньому процесі.

У суспільстві вже давно панує думка того, що багато в чому невідповідність між пропозицією робочої сили та попитом зумовлена недоліками та суперечностями традиційної системи фахової освіти, насамперед, іiі консервативністю, негнучкістю, відірваністю від практики, байдужістю до індивідуальності особистості та орієнтованістю на широкі маси, несистемністю інформаційних потоків. Проте, найголовніше - вона потребує від студента повного чи глибокого «занурення» виключно в навчальний процес так, що йому краще забути про інші види життєдіяльності. Саме тут виникають труднощі соціального, технологічного, а найважливіше, освітнього характеру. Соціологам слід було давно звернути увагу на дану проблему, адже той факт, що галузь вищої та професійної освіти в наш час перебуває, за великим рахунком, на утриманні держави, є ні що інше, як вираження суперечності між наявністю коштів 
у тих, хто хотів би навчатися, i їх можливостями увійти в рамки навчального процесу, що надається традиційною системою. Проте, мабуть, легше та спокійніше «складати» рейтинги, орієнтовані на створення «дутих» PR-іміджів, ніж дійсно досліджувати процеси розвитку суспільства та його проблеми.

Ми всі є членами нового інформаційного суспільства, яке відрізняють нові характеристики, умови та спосіб життя. Молоді люди, які виступають «основними споживачами» освітніх послуг, відчувають ці відмінності дуже гостро і саме 3 цих позицій все більше і більше висувають вимоги до змісту, рівня та якості освітнього процесу. Ці вимоги спрямовані на індивідуалізацію навчальних програм, відкритий доступ до освітніх ресурсів, комунікабельність студентів та викладачів, гнучкість та керованість навчального розкладу, наочність та практична значущість навчального матеріалу та ін. Крім того, не можна не звертати увагу, що навчання в наш час перевтілилось в супер-продукт, необхідний рівень якості якого має підтримуватися протягом усього активного життя людини. Дослідження показують, що тих знань, які «виносить» 3 вищого навчального закладу дипломований фахівець, вистачає йому на три роки, максимум на п'ять років. У галузі економіки та бізнесу старіння знань відбувається ще швидше. Отже, інтенсивність попиту на післядипломну освіту повинна збільшуватися. Проте, вузи реагують на це збільшення попиту збільшенням числа екстенсивних форм навчання (друга вища освіта, курси підвищення кваліфікації, програми навчання в рамках центрів додаткових освітніх послуг і т. п.).

Суспільні погляди сьогодні на процес навчання включають в себе наступне:

- $\quad$ навчання як процес надбання знань, досвіду та вмінь - це безперервний довічний процес;

- освіта вже не кваліфікується практикою як певна сума отриманих у вищому навчальному закладі знань, а як здатність ефективно діяти в реальних ситуаціях, ухвалювати правильні рішення та робити ефективні дії;

- цінність освіти професіонала багато в чому залежить від того, наскільки знання, уміння та навички, якими він володіє, входять у систему корпоративних знань, а також доповнюють та розвивають іï;

- ефективність навчання прямо пропорційно залежить від пошукової діяльності самого студента.

Віртуальна реальність, як і об'єктивна, надається людині через іiі відчуття в іï уявленні. Проте, якщо об'єктивна реальність відображається людською уявою, то віртуальна реальність $є$ повністю творенням такої уяви. Можна вважати, що світ, котрий виникає в нашій уяві, коли ми перечитуємо книгу чи дивимося кінофільм, також віртуальний. Але це не зовсім так. Цей світ виступає творенням чужої уяви, що зафіксоване в книзі або кінофільмі, то ми сприймаємо його так, як він зафіксований. Стосовно нас він є об'єктивним.

Віртуальна реальність - це термін, який характеризує особливий тип взаємодії між різнорідними об'єктами, що розташовані на різних ієрархічних щаблях, а також специфічні стосунки між ними - погодженості та інтерактивності. Об'єкти віртуального рівня створюються об'єктами нижчого рівня, проте, незважаючи на свій статус породжених, перебувають у взаємодії з об'єктами породжуючої реальності як онтологічно рівноправні. Сукупність віртуальних об'єктів стосовно породжуючої реальності, власне, й утворюють віртуальну реальність. Віртуальні об'єкти існують тільки тут і зараз, поки в «породжуючій реальності відбуваються генеруючі процеси; по завершенню процесу породження відповідні віртуальні об’єкти зникають» [2, с. 167].

Віртуальна реальність - це реальність, що може змінюватися нашою уявою, виникати тоді і там, коли і де ми забажаємо, щоб вона виникла. А у людської уяви можливості необмежені.

У своїй роботі «Онтологія віртуальної реальності» Н. Карпінський досліджує «...смислове зображення віртуальної реальності через різноманітний матеріал, намагаючись знайти в ньому характеристики віртуальності, зокрема на прикладі дзеркала, телефону, телевізора, сновидіння, літературної дійсності та внутрішньо-комп'ютерної образної реальності» [3, с. 13].

Розуміючи під процесом навчання процес формування у того, хто навчається, деякої системи знань, умінь та навичок дії, то можна стверджувати, що віртуальність виступає одним із його базових принципів. Наприклад, професор економіки розказує студентам-першокурсникам про часи Великої Депресії в США, а в їх уяві створюються образи безробіття, організованої злочинності, злиднів одних на тлі багатства та розкоші інших класів американського суспільства. У той же час у кожного зі студентів дані образи свої. Проте, головним $є$ те, що включилася уява та почалося ефективне запам'ятовування причинно-наслідкових зв'язків між фактами в системі знань кожного окремого індивіда.

3 технологічного боку, віртуальне навчання являє собою закономірний розвиток методів опанування інформаційних і засобів нових інформаційних технологій в системі освіти. Використання таких засобів не виступає самоціллю, а тільки засобом інтенсифікації та поглиблення навчального процесу. Цієї мети вже намагаються досягти принаймні протягом останніх 35 років - 3 моменту по- 
яви у вищих навчальних закладах перших зразків обчислювальної техніки. Проте лише сьогодні, коли комп'ютери дійсно стали набувати властивостей, що дають змогу називати їх інтегральними засобами обробки інформації і телекомунікації, випала нагода реально відчути результати досягнення поставленої мети. Річ у тому, що сучасна технологічна база дає змогу перетворити різноманітні знання, якими володіють вищі навчальні заклади, в єдиний віртуальний ресурс, який буде доступний студентові у будь-який час, в будь-якому місці та в будь-якому контексті, визначеному самим студентом.

У класичному процесі навчання всі навчальні ресурси реальні, а можливості доступу студента до них залежить від реального часу, реального місця та реального контексту. Режим, порядок та інтенсивність освіти за таких умов практично не залежать від учня. Але, мабуть, найгіршим є те, що навчальні програми та плани традиційного навчання орієнтуються в більшості випадків на простого студента. Проте, такий студент не безлика сутність - це маса. Зосереджуючи увагу на задоволенні масового попиту, система освіти на сьогоднішній день просто приречена мати масу людей, які незадоволені своєю освітою. Проте, є відомий нам давно вихід із такої ситуації: освітні програми та плани мають стати адаптивними, легко орієнтуватися не лише просто під вимоги особистості, але і під іiі освітній рівень, під динаміку iii навчання. Цього досить важко досягти, так як $€$ державний освітній стандарт. Тому доцільним буде, якщо навчальні програми будуть розроблятися не в рамках такого стандарту, а на його базі. Стандарт мусить бути мінімумом, від якого будуть відштовхуватись всі студенти, проте до закінчення навчання кожен із них приходить своїм шляхом. Технологія віртуального навчання є найоптимальнішим та найефективнішим способом для досягнення цієї мети.

Усвідомлення того, що XXI століття класичні університети мають виходити 3 неокласичної технології віртуального навчання, кожного року все більше і більше зміцнюється академічне середовище. На сьогоднішній день за даними International Data Corporation у світі налічується уже близько 200 університетів, що займаються он-лайн технологією навчання своїх студентів так же серйозно, як і традиційною. Результати не змушують себе чекати. В одних тільки США минулого року навчальні програми першої вищої освіти віртуально опановували 710000 чоловік, що складає приблизно 4,8 \% від загальної кількості американських студентів, яких налічується 14600 000. В майбутньому очікується збільшення популяції віртуальних студентів у США до 2230000 осіб, що повинно скласти 14,8 \% від загальної кількості студентів [4].
Явище віртуалізації суспільства стрімко проникає і в галузь наукової діяльності. Досить часто результати наукових проектів оформлюються у вигляді «електронних публікацій» в Інтернет-мережі та стають надбанням електронних журналів та електронних бібліотек. Тим самим світові запаси електронних наукових ресурсів безупинно зростають. Це ставить на порядок денний нову масштабну проблему формування ефективних способів пошуку необхідної студенту інформації в електронних мережах.

Важливим напрямом вирішення даної проблеми є те, щоб створити пошукові машини спеціальні види інформаційних технологій, що мають на меті спростити семантичний пошук інформації в різноманітних видах електронних бібліотек. У порівнянні з традиційними пошуковими машинами, що виокремлюють інформацію на базі ключових слів, які розміщені в запиті користувача, така програма, насамперед, намагається логічно проаналізувати поставлене їй запитання, «зрозуміти» його суть і тільки потім починає шукати адекватну цьому змісту інформацію. Цей цікавий напрям розвитку інтелектуальних мережевих технологій в майбутньому буде займати одне 3 найважливіших місць у нових умовах інформаційного суспільства. Технології віртуальної освіти стають досить ефективним засобом для наукового дослідження. Вони дозволяють створити модель розвитку багатьох реальних процесів та явищ у таких умовах їх протікання, які не можна або ж небезпечно створювати в реальній дійсності.

У роботі сучасного дослідника науковий експеримент 3 реальними об'єктами природи чи зразками нової техніки все частіше замінюється штучно створеними віртуальними моделями. Це дає змогу економити велику кількість часу, енергії та матеріальних затрат, і тому це корисно для науки і для суспільства. Але тут виникає небезпека заміщення фізичної реальності світом уявлення та фантазій, який в подальшому може стати неадекватним цій дійсності [5].

Віртуалізація системи навчання ефективно здійснюється і поширюється в розвинених країнах світу протягом останнього десятиліття. Мотивами для цього є три основні фактори:

збільшення вимог до рівня кваліфікації працівників у зв'язку з технологічним удосконаленням сучасного виробництва та галузі обслуговування населення;

- перехід промисловості на дрібносерійне виробництво при швидкому заміщенні моделей, яке потребує оперативної перепідготовки робітників більшості компаній;

- $\quad$ все більше розуміння в суспільстві ціннісного значення якісної освіти як особистого та національного надбання. 
Висновки. Таким чином, у системі освіти розпочався пошук нових форм навчання. Одними 3 них стали дистанційне навчання, безперервна освіта, транснаціональне навчання, віртуальна освіта 3 використанням мережевих інформаційних технологій.

Отже, віртуалізація освіти розкриває принципово нові можливості для подолання двох найважливіших та актуальніших проблем сучасного суспільства:

- збільшення доступності до відкритості якісної освіти (у тому числі для осіб з обмеженими фізичними можливостями);
- безперервності процесу навчання протягом усього людського життя, що вже на сьогоднішній день $є$ загальновизнаною потребою та вимогою, яка проголошена в документах ЮНЕСКО.

У той же самий час потрібно пам'ятати, що віртуальна система освіти не може бути визнана повноцінною тому, що вона принципово не в змозі повністю замінити особистий контакт студента та викладача, процеси їх особистого спілкування та взаємодії.

Освоєння віртуальної реальності, перетворення на повсякденність комунікативних процесів, здійснюваних у іiї рамках, є суттєвою передумовою для розвитку дистанційного навчання.

\section{БІБІЛІОГРАФІЧНІ ПОСИЛАННЯ}

1. Краткий словарь по социологии / под ред. Д. Гвишиани, Н. Лапи. - М.: Политиздат, 1988. - 564 с.

2. Степко М. Вища освіта України і Болонський процес: Навчальний посібник / М. Степко, Я. Болюбаш, В. Шинкарук, В. Грубінко, І. Бабин; за ред. В. Кременя. - Тернопіль: Богдан, 2004. - 384 с.

3. Карпінський Н. Онтологія віртуальної реальності / Н. Карпінський. - Київ: Мілленіум, 1995. - 352 с.

4. Топчій Т. Інституціоналізація безперервної освіти в Україні: факторна обумовленість: автореф. дис. на здобуття наук. ступеня канд. соціол. наук / Т. Топчій. - Харків, 2006. - 20 с.

5. Огаренко В. Зміна парадигми державного управління та моделі управління вищою освітою / В. Огаренко // Держава та регіони. - 2004. - № 1. - С. 75-80.

\section{REFERENCES}

1. Gvishiani, D., \& Lapi, N. (1988). Kratkij slovar'po sociologii [Short dictionary of sociology]. Moscow: Politvydav [in Ruissian].

2. Stepko, M., Bolyubash, Ya., Shynkaruk, V., Grubinko, V., \& Babyn, I. (2004). Vyshcha osvita Ukrainy i Bolonskyi protses [Higher study in Ukraine and the Bologna process]. Ternopil: Bogdan

3. Karpinskyi, N. (1995). Ontolohiia virtualnoi realnosti [Virtual reality ontology]. Kyiv: Millennium

4. Topchiy, T. (2006). Instytutsionalizatsiia bezperervnoi osvity v Ukraini: faktorna obumovlenist [Institutionalization of continuous study in Ukraine: factorial conditionality]. Extended abstract of candidate's thesis. Kharkiv

5. Ogarenko, V. (2004). Zmina paradyhmy derzhavnoho upravlinnia ta modeli upravlinnia vyshchoiu osvitoiu [Changing paradigms of state administration and model of higher studies management]. State and regions, 1, 75-80.

\section{Половая Наталія Олександрівна}

Викладач

Національний авіаційний університет

03680, м. Київ, просп. Космонавта Комарова, 1

\section{Polovaya Natalia}

Lecturer

National aviation university

1, Komarova Ave., 03680, Kyiv, Ukraine

Email: sosonovitch.natalia@ukr.net

Цитування: Половая Н. О. Віртуальне навчання як головний вектор нової інформаційної епохи / Н. О. Половая // Науково-теоретичний альманах «Грані». - 2018. - Т. 21. - № 3. - С. 56-62.

Citation: Polovaya, N.A. (2018). Virtualne navchannia yak holovnyi vektor novoi informatsiinoi epokhy [Virtual study as a main vector of new information epoch]. Scientific and theoretical almanac «Grani», 21(3), $56-62$. 